\title{
PENINGKATAN MOTIVASI BELAJAR MELALUI \\ BIMBINGAN DAN KONSELING ISLAMI
}

\author{
Ibnu Mahmudi*
}

\begin{abstract}
Abstrak
Tujuan Penelitian ini untuk mengetahui peningkatan motivasi belajar siswa melalui layanan bimbingan dan konseling Islami. Peningkatan motivasi belajar pada siswa di sekolah sebenarnya sudah dilakukan oleh konselor dan para guru melalui layanan pembelajaran dan layanan bimbingan dan konseling. Usaha peningkatan motivasi belajar tersebut belum menunjukkan hasil yang optimal, hal tersebut terbukti masih banyaknya anak usia sekolah yang melakukan kegiatan yang tidak sesuai dengan tugasnya pokoknya sebagai pelajar yaitu belajar, malah melakukan kegiatan yang tidak mengembangkan kemampuan belajarnya. Hasil penelitian Asroful (2011) menunjukkan 65\% siswa memiliki motivasi belajar rendah.
\end{abstract}

Hasil penelitian tindakan kelas yang dilakukan Asroful (2011) yang berupaya untuk meningkatkan motivasi belajar melalui bimbingan dan konseling Islami dengan tiga siklus menunjukkan adanya peningkatan motivasi belajar. Pada siklus I hanya $35 \%$ siswa memiliki motivasi belajar tinggi, pada siklus II meningkat menjadi 56\% siswa, dan pada siklus III mengalami peningkatan yang cukup signifikan yaitu $83 \%$ siswa mempunyai motivasi belajar tinggi.

Berdasarkan hasil tersebut maka dapat disimpulkan bahwa peningkatan motivasi belajar siswa dapat dilakukan melalui layanan bimbingan dan konseling Islami.

Kata kunci : Motivasi Belajar, Bimbingan dan Konseling Islami

* Ibnu Mahmudi adalah Dosen Bimbingan dan Konseling IKIP PGRI Madiun 


\section{A. Pendahuluan}

Motivasi dalam belajar diperlukan setiap manusia, karena pada dasarnya belajar itu sepanjang hayat. Dalam proses perkembangan belajar manusia akan mengalami pasang surut, kadang-kadang semangatnya kuat dan kadangkadang semangatnya lemah. Hal ini bisa terjadi karena ada beberapa faktor yang menyebabkannya, dan yang sudah populer penyebab tersebut berasal dari dalam dan dari luar dirinya.

Kondisi di atas terjadi pada sebagian besar siswa yang ada di sekolahsekolah baik di sekolah dasar, SLTP, SLTA bahkan juga terjadi di Perguruan Tinggi. Kenyataanya banyak siswa atau mahasiswa yang melakukan kegiatan yang semestinya bukan bagian dari tugas pokoknya misalnya perbuatan asusila yang dilakukan di warnet dan diberbagai temat lainnya, berpacaran yang mengarah pada perbuatan yang melanggar norma agama maupun norma masyarakat, menipu orangtua dengan meminta uang untuk biaya studi tetapi tidak digunakan untuk kepentingan studinya, malah digunakan untuk membeli minuman keras, dan obat-obat terlarang, serta untuk berfoya-foya.

Kenyataan di atas juga terjadi di lembaga pendidikan tinggi yang semetinya tidak pantas ada karena pendidikan tinggi arus harus bisa menjadi contoh untuk bisa diteladani bagi generasi muda terutama siswa di sekolah. Hal ini bisa dilihat di berbagai tayangan di media elektronik, seperti televisi maupun Internet dan media cetak lainnya, adanya tawuran antar mahasiswa di perguruan tinggi yang sampai saat ini belum jelas penyebabnya, namun patut diduga penyebab nya adalah adanya perasaan gengsi dan harga diri antar kelompok mahasiswa yang berbeda program studi dan fakultasnya.

Dari gambaran di atas, menunjukkan bahwa para siswa maupun mahasiswa sebagian masih ada yang belum memahami tujuan belajar/studinya, terbukti kegiatan yang dilakukan belum sepenuhnya mengarah kepada pencapaian tujuan belajarnya dan bahkan melakukan kegiatan yang bertentangan dengan tujuan belajarnya, mereka tidak termotivasi untuk berpikir kreatif dalam mengembangkan kemampuannya serta dalam melakukan aktivtas belajarnya belum dilakukan secara optimal, 
sehingga pencapaian tujuan pendidikan yang diharapkan masih jauh dari kenyataan.

Berbagai usaha sebenarnya sudah dilakukan oleh konselor, guru dan dosen (di Perguruan Tinggi) untuk memberikan motivasi kepada para siswa atau mahasiswa untuk lebih menfokuskan aktivitas belajarnya secara optimal dan bisa kreatif dalam mengembangkan kemampuannya. Namun demikian berbagai upaya yang dilakukan itu belum bisa mencapai hasil yang diharapkan sehingga diperlukan upaya lain yang bisa dilakukan konselor yaitu melalui bimbingan dan konseling Islami. Di dalam bimbingan dan konseling Islami selain motivasi belajar yang sudah kita ketahui yaitu motivasi yang berasal dari dalam dan dari luar diri individu, masih ada satu faktor penting yaitu motivasi spritual dalam hal ini ajaran agama Islam. Bimbingan dan konseling Islami di dalam memberikan bimbingan kepada siswa berdasarkan nilai-nilai dan norma-norma ajaran agama Islam, sehingga motivasi belajar siswa di sekolah akan lebih kuat apabila juga di dasarkan pada nilai ajaran agama bahwa belajar itu ibadah dan pada akhirnya akan mendapat pahala dari Allah SWT.

\section{B. Pembahasan}

\section{Motivasi Belajar}

\section{a. Pengertian Motivasi}

Winkel (dalam Asti Wahyuni 2007 : 24) berpendapat "motivasi adalah motif yang sudah menjadi aktif pada saat-saatmelakukan percobaan, sedangkan motif sudah ada dalam diri seseorang jauh sebelumorang itu melakukan suatu perbuatan".

M. Utsman Najati (dalam Abdul Rahman Saleh, 2009 : 183), mengatakan "motivasi adalah kekuatan pengerak yang membangkitkan aktivitas pada makhluk hidup, dan menimbulkan tingkah laku serta mengarahkannya menuju tujuan tertentu".

Selanjutnya M. Utsman Najati (dalam Abdul Rahman Saleh, 2009 : 183-184) membagi motivasi menjadi tiga komponen pokok, yaitu:

1) Menggerakkan. 
Dalam hal ini motivasi menimbulkan kekuatan pada individu, membawa seseorang untuk bertindak dengan cara tertentu. Misalnya kekuatan dalam hal ingatan, respons-respons efektif, dan kecenderungan mendapat kesenangan.

2) Mengarahkan.

Berarti motivasi mengarahkan tingkah laku. Dengan demikian ia menyediakan suatu orientasi tujuan. Tingkah laku individu diarahkan terhadap sesuatu.

3) Menopang.

Artinya, motivasi digunakan untuk menjaga dan menopang tingkah laku, lingkungan sekitar harus menguatkan intensitas dan arah dorongan-dorongan dan kekuatan-kekuatan individu.

Hoyt dan Miskel (dalam Abdul Rahman Saleh, 2009 : 184) mengemukakan motivasi adalah kekuatan-kekuatan yang kompleks yang memulai dan menjaga kegiatan-kegiatan yang diinginkan ke arah pencapaian tujuan-tujuan personal.

McDonald (dalam Syaiful Bahri Djamarah, 2008:148) mendefinisikan motivasi sebagai perubahan energi dalam diri seseorang yang ditandai dengan munculnya perasaan dan didahului dengan tanggapan terhadap adanya tujuan. Atas pandangan ini, maka tingkah laku yang digerakkan hampir pasti memiliki keterkaitan dengan kebutuhan dan tujuan yang ingin dicapai, baik yang bersifat pemuasan kebutuhan biologis, maupun dalam keterkaitannya dengan kebutuhan psikologis.

Menurut Al Ghazali (dalam Banyu Bening: 2011), munculnya tingkah laku psikologis manusia yang cenderung baik dan terpuji disebabkan oleh tiga faktor pendorong, yaitu:

1) Kebutuhan akan penghargaan berupa pahala dan surga dari Allah; kebutuhan ini merupakan peringkat paling dasar. Dorongan atau motivasi ini biasanya dimiliki oleh orang-orang awam dan mayoritas umat manusia.

2) Kebutuhan akan sanjungan dari Allah; kebutuhan ini termasuk 
kategori peringkat sedang. Motivasi ini dimiliki oleh orang-orang saleh, meskipun jumlahnya tidak banyak.

3) Kebutuhan akan keridloan Allah dan kedekatan dengan-Nya; motivasi ini menempati peringkat paling istimewa, seperti halnya motivasi para Nabi, shiddiqien, dan para ulama'.

Bertolak dari beberapa pendapat di atas, peneliti berpendapat bahwa pengertian motivasi adalah keseluruhan daya penggerak baik dari dalam diri maupun dari luar dengan menciptakan serangkaian usaha untuk menyediakan kondisi-kondisi tertentu yang menjamin kelangsungan dan memberikan arah pada kegiatan, sehingga tujuan yang dikehendaki oleh subjek itu dapat tercapai.

\section{b. Pengertian Belajar}

Cronbach (dalam Vitalis, 2008 : 7) menyatakan bahwa: " Learning is shown by a change in behaviour as e result of experience". Terjemahan bebas:"Hasil belajar yang baik harus melalui pengalaman. Pebelajar harus mengalami dengan kemampuan panca inderanya”.

Winkel (2009 : 59) berpendapat bahwa: "Belajar adalah aktivitas psikis (mental) yang berlangsung dalam interaksi dengan lingkungan yang menghasilakn perubahan-perubahan yang berupa: pengalaman, pengetahuan, pemahaman, ketrampilan dan nilai - sikap".

Menurut Abdul Rahman Saleh (2009 : 207) "Belajar adalah suatu bentuk pertumbuhan dalam diri seseorang yang dinyatakan dalam caracara bertingkah laku yang baru berkat pengalaman dan latihan".

Thursan Hakim (dalam Indra : 2009) mengemukakan "belajar adalah suatu proses perubahan di dalam kepribadian manusia, dan perubahan tersebut ditampakkan dalam bentuk peningkatan kualitas dan kuantitas tingkah laku seperti peningkatan kecakapan, pengetahuan, sikap, kebiasaan, pemahaman, keterampilan, daya pikir, dan lain-lain kemampuan".

Slameto (2010 : 2) mengatakan "belajar merupakan suatu proses usaha yang dilakukan seseorang untuk memperoleh suatu perubahan 
tingkah laku yang baru secara keseluruhan, sebagai hasil pengalamannya sendiri dalam interaksi dengan lingkungannya”.

Berpijak dari beberapa pendapat diatas, penulis mengartikan belajar merupakan suatu aktivitas yang dilakukan oleh individu dalam berinteraksi dengan lingkungan, sehingga terjadi perubahan tingkah laku, pengetahuan, ketrampilan, sikap, kebiasaan, kecakapan pada individu tersebut.

\section{c. Pengertian Motivasi Belajar}

Brophy (dalam Wahidnurrohman : 2011) pengertian dari "motivasi belajar adalah suatu kecenderungan siswa untuk melakukan kegiatan akademi yang berarti dan berguna, untuk meraih hasil yang baik dari kegiatan tersebut".

Winkle (2009 : 169), mengatakan bahwa "motivasi belajar adalah keseluruhan daya penggerak psikis didalam diri siswa yang menimbulkan kegiatan belajar, menjamin kelangsungan kegiatan belajar dan memberikan arah pada kegiatan belajar itu demi mencapai suatu tujuan".

Hamzah B (2007 : 23) menyebutkan "motivasi belajar ialah dorongan internal dan eksternal pada siswa-siswa yang sedang belajar untuk mengadakan perubahan tingkah laku pada umumnya dengan beberapa indikator atau unsur yang mendukung".

Sardiman (1994 : 75) mengemukakan "motivasi belajar sebagai keseluruhan daya pengerak didalam diri siswa yang menimbulkan kegiatan belajar, yang menjamin kelangsungan dari kegiatan belajar dan memberikan arah pada kegiatan belajar, sehingga tujuan yang dikehendaki oleh subjek belajar itu dapat tercapai".

Wlodkowski dan Jaynes (dalam Wahidnurrohman: 2011) motivasi belajar merupakan suatu proses internal yang ada dalam diri seseorang yang memberikan gairah atau semangat dalam belajar, mengandung usaha untuk mencapai tujuan belajar, dimana terdapat pemahaman dan pengembangan belajar, dijelaskannya lagi, bahwa membantu anak 
dalam mengembangkan sebuah motivasi belajar dalam pengertian kependidikan secara luas yaitu menilai dan menyenangi membaca, menulis, berpikir, menghitung, memecahkan masalah.

Berdasar pengertian dari beberapa ahli yang telah dipaparkan sebelumnya, penulis mendefinikan motivasi belajar merupakan, keseluruhan daya penggerak baik dari dalam diri maupun luar diri siswa yang menimbulkan kegiatan belajar dan memberikan arah pada kegiatan belajar, sehingga siswa tidak hanya belajar namun juga menghargai, menikmati dan mengerti benar akan hal yang dipelajarinya.

\section{d. Indikator Motivasi Belajar}

Ada beberapa ciri anak yang telah mempunyai motivasi belajar antaraa lain, menurut Sardiman (1994 : 83) bahwa motivasi yang ada dalam diri seseorang memiliki ciri-ciri sebagai berikut:

1) Tekun menghadapi tugas (dapat bekerja terus menerus dalam waktu yang lama, tidak pernah berhenti sebelum selesai).

2) Ulet menghadapi kesulitan (tidak lekas putus asa). Tidak memerlukan dorongan dari luar untuk berprestasi sebaik mungkin (tidak cepat puas dengan prestasi yang telah dicapai).

3) Menunjukkan minat terhadap bermacam-macam masalah orang dewasa (misalnya masalah pembangunan agama, politik, ekonomi, keadilan, pemberantasan korupsi, penentang setiap tindak criminal, amoral dan lain-lain).

4) Lebih senang bekerja mandiri.

5) Cepat bosan pada tugas-tugas yang rutin (hal-hal yang bersifat mekanis, berulang-ulang begitu saja, sehingga kurang kreatif).

6) Dapat mempertahankan pendapatnya (kalau sudah yakin akan sesuatu).

7) Tidak pernah mudah melepaskan hal yang sudah diyakini.

8) Senang mencari dan memecahkan masalah soal-soal.

Apabila seseorang telah memiliki ciri-ciri motivasi di atas maka 
orang tersebut selalu memiliki motivasi yang cukup kuat. Kegiatan belajar mengajar akan berhasil baik, kalau siswa tekun mengerjakan tugas, ulet dalam memecahkan berbagai masalah dan hambatan secara mandiri. Selain itu siswa juga harus peka dan responsif terhadap masalah umum dan bagaimana memikirkan pemecahannya. Siswa yang telah termotivasi memiliki keinginan dan harapan untuk berhasil dan apabila mengalami kegagalan mereka akan berusaha keras untuk mencapai keberhasilan itu yang ditunjukkan dalam prestasi belajarnya. Dengan kata lain dengan adanya usaha yang tekun dan terutama didasari adanya motivasi maka seseorang yang belajar akan melahirkan prestasi belajar yang baik.

\section{e. Macam-macam Motivasi}

Woodworth dan Marquis (dalam Abdul Rahman Saleh, 2009: 193) menggolongkan dan membagi motivasi menjadi tiga macam, yaitu:

1) Kebutuhan-kebutuhan organis (Organic Motive)

Motivasi ini berhubungan dengan kebutuhan-kebutuhan bagian dalam tubuh (kebutuhan-kebutuhan organis), seperti: lapar/haus, kebutuhan bergerak dan beristirahat/tidur, dan sebagainya.

2) Motivasi darurat (Emergency Motive)

Motivasi ini timbul jika situasi menuntut timbulnya tindakan yang cepat dan kuat karena perangsang dari luar yang menarik manusia atau suatu organisme. Motivasi darurat mencakup dorongan untuk menyelamatkan diri, dorongan untuk membalas, dorongan untuk berusaha, dorongan untuk mengejar, dan sebagainya. Contoh motif ini antara lain : melarikan diri dari bahaya, berkelahi dan sebagainya.

3) Motivasi obyektif (Objective Motive)

Motif obyektif adalah motif yang diarahkan atau ditujukan ke suatu obyek atau tujuan tertentu di sekitar kita. Motif ini timbul karena adanya dorongan dari dalam diri kita (kita menyadarinya). Motivasi ini timbul karena dorongan untuk menghadapi dunia secara efektif. Contoh: motif menyelidiki, menggunakan lingkungan. 
Selain kedua tokoh di atas, beberapa psikologi (dalam Abdul Rahman Saleh, 2009 : 194) ada yang membagi motivasi menjadi dua, yaitu:

1) Motivasi Intrinsik

Jenis motivasi ini timbul dari dalam diri individu sendiri tanpa ada paksaan dorongan orang lain, tetapi atas dasar kemauan sendiri, untuk melakukan sesuatu. Seperti seorang peserta didik yang gemar membaca, maka ia tidak perlu disuruh-suruh untuk membaca karena membaca tidak hanya menjadi aktifitas kesenangannya, tetapi bisa jadi telah menjadi kebutuhannya.

Dalam proses belajar, motivasi intrinsik ini memiliki pengaruh yang lebih efektif karena motivasi intrinsik relatif lebih lama dan tidak tergantung pada motivasi dari luar (ekstrinsik). Meskipun demikian, ketika motif intrinsik tidak cukup potensial pada peserta didik, maka pendidik perlu menyiasati hadirnya motif-motif ekstrinsik.

Menurut Arden N. Frandsen (dalam Banyu Bening: 2011), yang termasuk dalam motivasi intrinsik untuk belajar antara lain adalah:

(a) Dorongan ingin tahu dan ingin menyelidiki dunia yang lebih luas.

(b) Adanya sifat positif dan kreatif yang ada pada manusia dan keinginan untuk maju.

(c) Adanya keinginan untuk mencapai prestasi sehingga mendapat dukungan dari orang-orang penting, misalnya orang tua, saudara, guru, atau teman-teman, dan lain sebagainya.

(d) Adanya kebutuhan untuk menguasai ilmu atau pengetahuan yang berguna bagi dirinya, dan lain-lain.

2) Motivasi Ekstrinsik.

Jenis motivasi ini timbul sebagai akibat pengaruh dari luar individu, apakah karena adanya ajakan, suruhan, atau paksaan dari orang lain sehingga dengan keadaan demikian peserta didik mau melakukan sesuatu atau belajar. 
Motivasi ekstrinsik ini mutlak diperlukan bagi peserta didik yang tidak ada motivasi di dalam dirinya. Di sini peran dari orang tua, guru, masyarakat serta lingkungan sekitar peserta didik harus memberi respons yang positif bagi peserta didik, sebab jika tidak akan mempengaruhi semangat belajar peserta didik menjadi lemah. Adapun yang termasuk ke dalam motivasi ekstrinsik adalah pujian, peraturan, tata tertib, teladan guru, orang tua, dan lain sebagainya.

Motivasi ekstrinsik ini tidak bertahan lama, sebab bila umpanumpan untuk memotivasi masih menarik, maka kegiatan masih tetap berjalan, namun tidak selamanya seorang guru dan juga orang tua maupun lingkunngan sekitarnya mampu terus mengumpan peserta didik untuk dapat mengikuti kegiatan belajar mengajar. Oleh karena itulah meskipun telah digunakan beberapa metode dalam mengajar masih ada anak yang belum mampu mengikuti proses belajar secara maksimal.

\section{Bimbingan dan Konseling Islami}

\section{a. Pengertian Bimbingan dan Konseling}

1) Pengertian Bimbingan

Secara umum bimbingan dapat didefinisikan sebagai bantuan atau pertolongan yang diberikan oleh Konselor (orang yang berkompeten dalam bimbingan) kepada Konseli/Individu/siswa agar dapat memahami, menerima dan menyelesaikan masalahnya serta dapat mengembangkan dirinya secara optimal sehingga dapat tercapai kebahagiaan dan kesejahteraan hidupnya.

2) Pengertian Konseling

Secara umum konseling dapat didefinisikan sebagai proses bantuan/komunikasi langsung yang dilakukan oleh Konselor dengan konseli, yang bertujuan memberikan bantuan kepadanya dalam merubah sikap dan tingkah lakunya. 
3) Pengertian Bimbingan dan Konseling Islami

Berdasarkan hasil Seminar tentang Bimbingan dan Konseling Islami yang dilakukan oleh Universitas Islam Indonesia (UII) Yogyakarta pada tanggal 15-16 Mei 1985. Kemudian menghasilkan rumusan tentang Bimbingan dan Konseling Islami sebagai berikut:

a) Anwar Sutoyo, (2007: hal 19), memberikan pengertian Bimbingan dan Konseling Islami sebagai "Suatu proses dalam bimbingan dan konseling yang dilakukan mendasarkan pada ajaran Islam, untuk membantu individu yang mempunyai masalah guna mencapai kebahagiaan dunia dan akhirat."

b) Pembimbingnya adalah individu yang memiliki kewenangan (kompetensi) untuk melakukan Bimbingan dan konseling Islami yaitu : 1) Konselor (ahli bimbingan dan konseling, 2) Ahli psikologi (psikolog), 3) Ahli pendidikan (pedagogik), 4) Ahli agama Islam (Ulama), 5) Dokter dan 6) Pekerja Sosial.

\section{b. Tujuan Bimbingan dan Konseling Islami}

Tujuan akhir yang ingin dicapai melalui konseling islami adalah agar fitrah yang akan dikaruniakan Allah kepada individu bisa berkembang dan berfungsi dengan baik, sehingga menjadi pribadi kaaffah, dan secara bertahap mampu mengaktualisasikan apa yang diimaninya itu dalam kehidupan sehari-hari, yang tampil dalam bentuk kepatuhan terhadap hukum-hukum Allah dalam melaksanakan tugas kekhalifahan di bumi, dan ketaatan dalam beribadah dengan mematuhi segala perintah-Nya dan menjauhi larangan-Nya. Dengan kata lain, tujuan konseling model Islami ini adalah meningkatkan iman, Islam dan ikhsan individu yang dibimbing sehingga menjadi pribadi yang utuh. Dan pada akhirnya diharapkan mereka bisa hidup bahagia di dunia dan akhirat.

Tujuan jangka pendek yang diharapkan bisa diccapai melalui konseling islami adalah terbinanya Iman (fitrah) individu sehingga 
membuahkan amal shaleh yang dilandasi dengan keyakinan yang benar bahwa:

1) Manusia adalah makhluk ciptaan Allah yang harus selalu tunduk dan patuh pada segala aturan-Nya.

2) Selalu ada kebaikan (hikmah) di balik ketentuan (takdir) Allah yang berlaku atas dirinya.

3) Manusia adalah hamba Allah, yang harus beribadah hanya kepadaNya sepanjang hayat.

4) Ada ffitrah (iman) yang diokaruniakan Allah kepada setiap manusia, jika fitrah iman dikembangkan dengan baik, akan menjadi pendorong, pengendali, dan sekaligus pemberi arah bagi fitrah jasmani, rohani, dan nafs akan membuahkan amal saleh yang menjamin kehidupannya selamat di dunia dan akhirat.

5) Esensi iman bukan sekedar ucapan dengan mulut, tetapi lebih dari itu adalah membenarkan dengan hati, dan mewujudkan dalam amal perbuatan.

6) Hanya dengan melaksanakan syari'at agama secara benar, potensi yang dikaruniakan Allah kepadanya bisa berkembang optimaal dan selamat dalam kehidupan di dunia dan akhirat.

\section{c. Tahap-tahap Bimbingan dan Konseling Islami}

1) Meyakinkan individu mengenai hal-hal sesuai dengan kebutuhan

a) Posisi manusia sebagai makhluk ciptaan Allah, bahwa ada hukum-hukum atau ketentuan yang berlaku bagi semua manusia.

b) Status manusia sebagai hamba Allah yang harus selalu tunduk dan patuh kepada-Nya.

c) Tujuan Allah menciptakan manusia adalah agar manusia melaksanakan amanah dalam bidang masing-masing sesuai dengan ketentuan Allah (khalofah fil ardh) dan sekaligus beribadah kepada-Nya. 
d) Ada fitrah yang dikaruniakan Allah kepada manusia, bahwa manusia sejak lahir dilengkapi dengan fitrah berupa iman dan taat kepada-Nya. Tugas manusia adalah memelihara, mengembangkan, dan ketika menjauh segera kembali kepadaNya.

e) Iman yang benar sangat penting bagi keselamatan hidupnya di dunia dan akhirat. Tugas manusia adalah memelihara dan menyuburkannya dengan selalu mempelajari dan mentaati tuntunan agama.

f) Iman bukan hanya pengakuan dengan mulut, tetapi lebih dari itu adalah membenarkan dengan hati dan mewujudkan apa yang diimaninya itu dalam kehidupan sehari-hari.

g) Ada hikmah di balik musibah, ibadah dan syari'ah yang ditetapkan Allah untuk manusia. Kewajiban manusia adalah menerima dengan ikhlas apa yang ditetapkan Allah untuknya dan melaksanakan sesuai syari'at-Nya

h) Adalah suatu keharusan menanamkan aqidah yang benar pada anak sejak dini, menjauhkan anak dari syirik, dan membiasakan setiap anggota keluarga melaksanakan ibadah dan beramal shaleh seccara benar dan istiqamah.

i) Ada syetan yang selalu berupaya menyesatkan manusia dari jalan Allah. Agar manusia selamat dari bujuk rayu setan, Allah telah menganugerahkan potensi berupa akal pikiran, perasaan dan tuntunan agama kepda manusia.

j) Ada hak manusia untuk berikhtiar atau berusaha semaksimal mungkin, tetapi perlu diingat bahwa sebagian dari keberhasilannya masih tergantung pada idzin Allah.

k) Tugas konselor hanyalah membantu, individu sendiri yang harus berupaya sekuat tenaga dan kemampuannya untuk hidup sesuai dengan tuntunan agama.

2) Mendorong dan membantu individu memahami dan mengamalkan ajaran agama secara benar. 
Pada tahap ini konselor mengingatkan kepada individu bahwa:

a) agar individu selamat hidupanya di dunia dan akhirat, maka ia harus menjadikan ajaran agama sebagai pedoman dalam setiap langkahnya, dan untuk itu individu harus memahami ajaran Islam secara baik dan benar,

b) mengningat ajaran agama itu amat luas, maka individu perlu menyisihkan sebagian waktu dan tenaganya untuk mempelajari ajaran agama secara benar dengan memanfaatkan berbagai sumber dan media.

Peran konselor pada tahap ini adalah sebagai pendorong dan sekaligus pendamping bagi individu dalam mempelajari dan mengamalkan ajaran agama, dengan demikian diharapkan secara bertahap individu mampu membimbing dirinya sendiri. Oleh karena peran itu, maka konsekuensinya konselor sendiri harus lebih dahulu memahami bahkan sebisa mungkin telah mengamalkan apa yang dipahaminya dari ajaran agama itu dalam kehidupan sehari-hari. Dari tahapan ini nampak pula bahwa agar individu bisa mandiri, maka individu perlu belajar sepanjang hayat dan sejagad hayat (lifelong learning and lifewide learning), bahkan lebih dari itu adalah mengamalkan apa yang dipelajarinya itu sebagai ibdah sepanjang hayat. (lifelong worship).

3) Mendorong dan membantu individu memahami dan mengamalkan iman, Islam dan ikhsan.

Mengingat iman bukan hanya ucapan, tetapi harus diaktualisasikan dalam kehidupan sehari-hari dalam bentuk ibadah (mahdhoh dan ghoiru mahdhoh), maka individu perlu didorong dan dibantu untuk mengamalkan apa yang dipelajarinya itu secara benar dan istiqomah. Maka konselor perlu mendorong dan membantu individu memahami hal-hal berikut beserta aktualisasinya dalam kehidupan sehari-hari.

a) Aktulisasi rukun iman dalam kehidupan sehari-hari

(1) Hanya beribadah kepada Allah dan tidak kepada yang lain. 
(2) Beribadah dengan niat yang tulus hanya semata-mata karena Allah.

(3) Menyerahkan hasil usahanya hanya kepada Allah.

(4) Yakin bahwa Allah memiliki makhluk gaib berupa malaikat.

(5) Mematuhi apa diajarkan Allah dalam Al-Qur'an.

(6) Mematuhi pa yang diajarkan oleh Rasulullah.

(7) Ikhlas menerima ketentuan Allahatas dirinya.

(8) Yakin bahwa akan datang hari pembalasan dan setiap manusia akan mendapatkan balasan dari apa yang dilakukannya selama hidup di dunia.

b) Aktualisasi rukum Islam dalam kehidupan sehari-hari.

(1) Meninggalkan segala macam bentuk syirik.

(2) Melaksanakan syari'at yang dibawa Rasulullah SAW.

(3) Melaksanakan shalat wajib dan sunnah secara benar.

(4) Ikhlas mengeluarkan sebagian hartanya untuk infaq, zakat dan atau shadaqoh.

(5) Melaksanakan puasa wajib dan sunnah secara benar.

(6) Menunaikan ibadah hajji sesuai ajaran agama.

c) Aktualisasi Ikhsan dalam kehidupan sehari-hari.

(1) Selalu menjaga lidah (selalu berbicara dengan baik, berbicara hanya yang bermanfaat, tidak berdusta, tidak mengadu domba, tidak ghibah)

(2) Menjauhkan diri dari penyakit hati (tidak berburuk sangka, hasud, irihati, sombong, dendam, riya, mudah marah)

(3) Menjauhkan dir dari perbuatan yang membahayakan. (tidak merokok, mubadzirkanharta, makan dan minum secara berlebihan)

(4) Selalu menjaga kesehatan (jika sakit ia berobat, tidak berobat dengan sesuatu yang diharamkan Allah, menjaga diri dari perbuatan yang membahayakan tubuh dan mental) 
(5) Sikap terhadap sesama muslim: jika bertemu teman memberi salam dan berjabat tangan, bermuka manis, menghormati, dan berkasih sayang.

(6) Sikap terhadap orangtua (ayah dan ibu): senantiasa berbuat baik, tidak mendurhakai, bertutur kata lembut, mendo'akan orangtua, dan menjaga hubungan baik dengan sahabat orangtua.

\section{Peningkatan Motivasi Belajar Melalui Bimbingan dan Konseling}

\section{Islami}

Beberapa Motivasi Aktivitas Hidup Manusia yang Dianjurkan Islam.

Hanna Djumhana, dkk (2003 : 155-156) mengemukakan beberapa motivasi aktivitas hidup manusia yang dianjurkan oleh islam, yaitu:

a. Tidak ada motivasi atau tendensi apapun dalam ibadah, hidup dan mati kecuali semata-mata karena Allah. Katakanlah! Sesungguhnya shalatku, ibadahku, hidupku dan matiku hanyalah untuk Allah, Tuhan semesta alam (QS. $6: 162)$.

b. Semata-mata ikhlas karena Allah, sebab hal itu merupakan bentuk beragama yang benar. Padahal mereka tidak disuruh kecuali supaya mereka menyembah Allah dengan memurnikan ketaatan kepada-Nya dalam (menjalankan) agama dengan lurus dan supaya mereka mendirikan shalat dan menunaikan zakat dan yang demikian itulah agama yang lurus (QS. $98: 5)$.

c. Untuk mencapai kebaikan dan kebahagiaan hidup di dunia dan di akhirat dan terhindar dari siksaan apai nereka. Dan diantara mereka ada orang yang mendo'a, ya Tuhan kami berikan kami kebaikan di dunia dan kebaikan di akhirat serta periharalah kami dari siksa neraka (QS. 2 : 201).

d. Untuk mencapai keberuntungan akhirat, sebab dengan mencari keuntungan akhirat ini ia mendapat keberuntungan dunia. Namun jika hanya ingin keberuntungan dunia maka akhiratnya tidak dapat. Barang siapa yang menghendaki keuntungan di akhirat akan kami tambah 
keuntungan itu baginya, dan barang siapa yang menghendaki keuntungan di dunia kami berikan kepadanya sebagian dari keuntungan di dunia dan tidak ada baginya suatu bahagianpun di akhirat (QS. $42: 20)$.

\section{Penutup}

Berpijak pada hasil penelitian tindakan kelas yang dilakukan Asroful (2011) menunjukkan adanya peningkatkan motivasi belajar melalui bimbingan dan konseling Islami, pada siklus I hanya 35\% siswa memiliki motivasi belajar tinggi, pada siklus II meningkat menjadi 56\% siswa, dan pada siklus III mengalami peningkatan yang cukup signifikan yaitu $83 \%$ siswa mempunyai motivasi belajar tinggbahwa pada uraian di atas maka dapat disimpulkan bahwa layanan bimbingan dan konseling Islami dapat meningkatkan motivasi belajar siswa di sekolah.

\section{Daftar Pustaka}

Abdul Rahman Shaleh, dkk. 2004. Psikologi Suatu Pengantar dalam Perspektif Islam. Jakarta: Prenada Media.

Al-Qur'an dan Terjemahnya, Departemen Agama Republik Indonesia.

Anwar Sutoyo. 2007. Bimbingan dan Konseling Islamai. Semarang : CV. Cipta Prima Nusantara.

Asti Wahyuni. 2007. Pengaruh Motivasi Belajar dan Metode Pembelajaran Terhadap Prestasi Belajar Akuntansi Siswa Kelas 1 SMK PELITA NUSANTARA 1 Semarang. Semarang: Program Studi Akuntansi Fakultas Ekonomi Universitas Negeri Semarang.

Banyu Bening. 2011. Pengertian Motivasi Belajar dan Jenisnya, (online), (http://www.elfilany.com, diakses 11 Maret 2011).

Eko Suprapto. 2009. Faktor-Faktor yang Mempengaruhi Proses Belajar, (online), (http://ekosuprapto.wordpress.com, diakses 3 Maret 2011).

Hamzah BU. 2007. Teori Motivasi dan Pengukurannya. Jakarta: PT. Bumi Aksara. 
Hanna Djumhana, dkk. 2003. Islam untuk Disiplin Ilmu Psikologi. Departemen Agama.

Imam Safi'i. 2008. Motivasi Belajar,(online),(http://kangsaviking.wordpress.com, diakses 23 Maret 2011).

Indra $\quad$ Munawar. 2009. Pengertian Belajar, (online), (http://indramunawar.blogspot.com, diakses 22 Februari 2011).

Mizan. 2011. Bimbingan dan Konseling Islami, (online), (http://www.mizanpoenya.co.cc, dikases 3 Maret 2011)

Mohamad Zainal A. 2009. Pengertian Bimbingan dan Konseling Islam, (online), (http://www.masbied.com, diakses 5 Maret 2011).

Sardiman AM. 1994. Interaksi dan Motivasi Belajar Mengajar. Jakarta: PT. Raja Grafindo Persada.

Slameto. 2010. Belajar dan Faktor-Faktor yang Mempengaruhinya. Jakarta: PT. Rineka Cipta

Suharsimi Arikunto, dkk. 2006. Penelitian Tindakan Kelas.Jakarta: Bumi Aksara.

Syaiful Bahri. 2008. Psikologi Belajar. Jakarta: Rineka Cipta.

Vitalis DS. 2008. Diagnosis Kesulitan dan Kegagalan Belajar. Diktat mata kuliah mahasiswa program studi bimbingan dan konseling IKIP PGRI Madiun.

Wahidnurrohman. 2011. Pengertian Motivasi Belajar,(online), (http://wahid07.wordpress.com, diakses 20 Maret 2011).

Wina Sanjaya. 2009. Penelitian Tindakan Kelas. Jakarta: Prenada Media.

WS Winkel. 2009. Psikologi Pengajaran. Yogyakarta: Media Abadi. 